Available online at www.banglajol.info

Bangladesh J. Sci. Ind. Res. 47(1), 83-88, 2012.

\section{BANGLADESH JOURNAL OF SCIENTIFIC AND INDUSTRIAL RESEARCH}

E-mail: bjsir07@gmail.com

\title{
Ground-level Concentration of Ozone in Ambient Air in Chittagong (Bangladesh) City
}

\author{
B. A. Begum*1, G. Saroar ${ }^{2}$, M. Nasiruddin ${ }^{2}$, S. K. Biswas ${ }^{2}$ \\ ${ }^{a}$ Chemistry Division, Atomic Energy Centre, Dhaka and Department of Environment ${ }^{b}$ Clean Air \& Sustainable \\ Environment, Dhaka, Bangladesh
}

\begin{abstract}
The distribution of the ground-level ozone concentration in Chittagong city was continuously monitored at air monitoring station in Chittagong city during period of December 2006 to December 2007. The results of this study have revealed that the ground-level ozone concentration in Chittagong city varied from season to season. The highest ground-level ozone concentration was found in winter. The groundlevel ozone concentration has also a clear diurnal cycle - with higher values in the daytime and notably becomes zero at night depending on season. Meteorological conditions are known to influence the formation and dispersion of ground-level ozone concentration. At temperature lower than $20^{\circ} \mathrm{C}$, the concentration of ozone becomes high where as at high temperature $\left(>30^{\circ} \mathrm{C}\right)$, the concentration becomes low. It has also been found that at low wind speed, the ozone concentration is high and at high wind speed, the concentration becomes low due to dispersion. The results also establish that the during the study periods, the ozone concentration was below the Bangladesh National Ambient Air Quality Standard (BNAAQS) of 80 ppb (annual average).
\end{abstract}

Key words : Diurnal cycle, Ozone, BNAAQS

\section{Introduction}

The ground-level ozone air pollution is of great concern because of its adverse effects on human health, vegetations and ecosystems (Cristofanelli and Bonasoni, 2009). Groundlevel ozone generally do not emit from any source directly to the atmosphere. It the results of photochemical reactions between oxides nitrogen $\left(\mathrm{NO}_{\mathrm{x}}\right)$ and volatile organic compounds (VOCs) in the presence of sunlight (Pudasainee et. al, 2006. Emissions of $\mathrm{NO}_{\mathrm{x}}$ are primarily from motor vehicle engines, power plants, industrial boilers and burning of fossil fuels. Main sources of VOCs emissions are motor vehicle emissions, gasoline vapor, and chemical solvents (Parra et al, 2009).

High concentrations of ground-level ozone are becoming a greater and greater concern each year because it constitutes the main part of photochemical smog. Photochemical ground-level ozone formation depends on a number of natural and anthropogenic factors. Typical summer fair weather conditions are responsible for an increase in ground-level ozone production (Jacob and Winner, 2009. The most efficient ozone formation reactions are driven by solar radiation and its precursors such $\mathrm{NO}_{\mathrm{x}}$ and VOCs. Meteorological parameters (temperature, wind speed and direction, solar radiation, humidity) highly influence the formation and dispersion of this pollutants and the concentration varying widely from region to region, with the time of year, and the time of day (Hunova et al, 2004).
In view of the importance of the ground-level ozone concentration, this study intends to assess the ground-level ozone concentrations in the Chittagong air, the second largest city of Bangladesh. The ozone concentration data was obtained from Chittagong continuous air-monitoring station (CAMS) established in 2006 and it was tried to relate with $\mathrm{NO}_{\mathrm{x}}$ and meteorological data for better understanding of the groundlevel ozone concentrations.

\section{Methodology}

\section{Sampling}

A Continuous Air Monitoring Station (CAMS) is operated in Chittagong to measure criteria pollutants. The location of the CAMS is in the Chittagong Television Station Campus at Khulshi, which is on a hilltop about $2.5 \mathrm{~km}$ northwest of the downtown and about 100 meters above the surrounding area (Figure 1).

The location thus is unaffected by nearby air pollution sources, and it is representative of the air pollution concentrations of the city. The gaseous pollutants were collected from the on line air monitoring has been designed by Environment S.A, French for monitoring $\mathrm{SO}_{2}, \mathrm{NO}_{\mathrm{x}}, \mathrm{CO}, \mathrm{O}_{3}$ and Hydrocarbon \& Non-methane hydrocarbon. Air sampling 


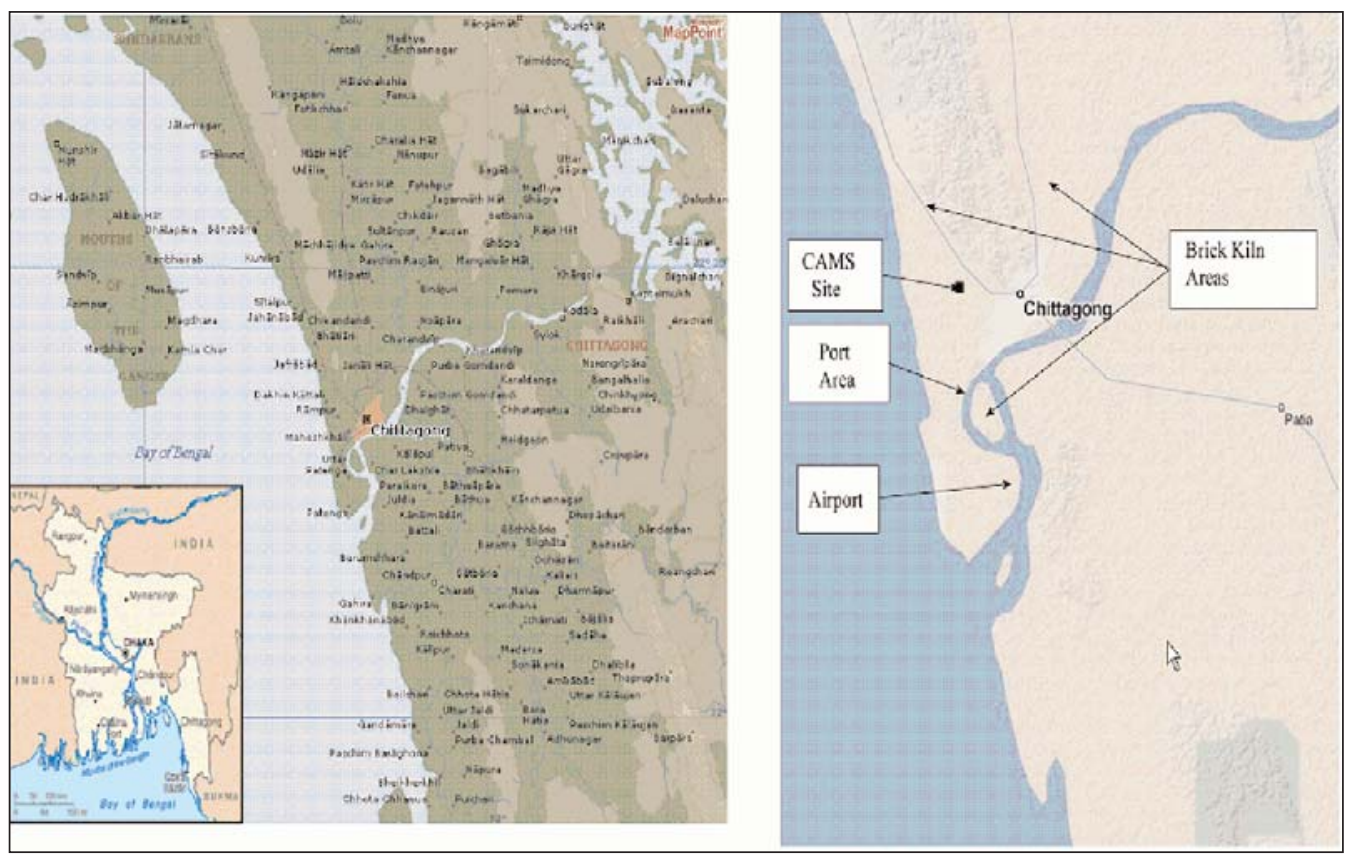

Fig. 1: Map of sampling location

is done continuously and the data are recorded in Data logger as $15 \mathrm{~min}$ average. The raw data of the gaseous pollutant, namely $\mathrm{SO}_{2}, \mathrm{NO}_{\mathrm{x}} \mathrm{x}, \mathrm{CO}$, and $\mathrm{O}_{3}$ collected from December 2006 to December 2007 were obtained CAMS, Chittagong. Brief information about the gaseous pollutant measurements was given in Table I. removes only ozone from the sample air. This scrubbed sample absorbs UV light in the measurement cell and intensity of UV light is measured again. Finally, the difference between the two intensity of UV light (absorption by non-scrubbed sample and absorption by scrubbed sample) is used to determine the ozone concentration. The analyzer is calibrated by

Table I: Details of different analyzers used for the measurements at Chittagong CAMS

\begin{tabular}{l|l|c|c|c}
\hline Gas & Method & Standard and Model & MDL & Response time (s) \\
\hline Ozone & UV Photometry & FEM \& ML9810B & $0.4 \mathrm{ppb}$ & 10 \\
$\mathrm{CO}$ & Non dispersive IR (NDIR) with & FEM \& ML9830B & $50 \mathrm{ppb}$ & 60 \\
& Gas Filter Correlation & FEM \& ML9850B & $1 \mathrm{ppb}$ & 10 \\
$\mathrm{SO}_{\mathrm{x}}$ & UV Fluorescence & FEM \& ML9841B & $1 \mathrm{ppb}$ & 10 \\
$\mathrm{NO}_{\mathrm{x}}$ & Gas Phase Chemiluminescence & & \\
\hline
\end{tabular}

\section{Working principle of ozone analyzer}

The O3-42M is a continuous ozone analyzer (Figure 2). It uses the principle of ozone detection by absorption in ultraviolet light also known as UV photometry. The air sample is injected into the analyzer by an internal pump. The sample air goes through a particulate filter to remove particulates and other contaminants from the sample air. Then the sample goes into the measurement cell where the ozone molecules absorb the UV rays at $253.7 \mathrm{~nm}$ wavelength. Again the sample enters into the measurement cell through an ozone scrubber. The ozone scrubber contains manganese dioxide, which known concentration of ozone produced from built in ozone generator.

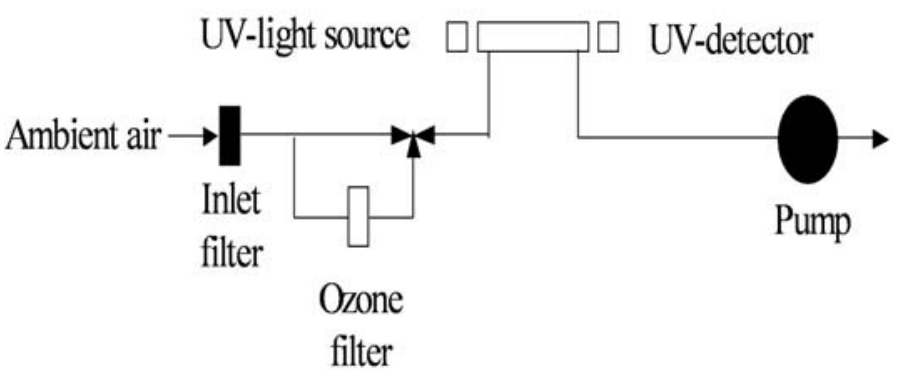

Fig. 2: Simple flow diagram of $\mathrm{O}_{3}$ analyzer 


\section{Meteorological Conditions}

In Bangladesh, the climate is characterized by high temperatures and high humidity during most of the year, and distinctly marked seasonal variations in precipitation. Figure 3 shows the general wind pattern at Chittagong. According to meteorological conditions, the year can be divided into four seasons, pre-monsoon (March-May), monsoon (JuneSeptember), post-monsoon (October-November) and winter (December-February) (Begum et al, 2006). Winter is characterized by dry soil conditions, low relative humidity, scanty rainfall and low speed northwesterly winds. The rainfall and wind speed become moderately strong and relative humidity increases in the pre-monsoon season when the prevailing direction is southwesterly (marine). During the monsoon season, the wind speed further increases and the air mass is purely marine in nature. In the post-monsoon season, the rainfall and relative humidity decrease, as does the wind speed. The direction starts shifting back to northerly. The meteorological data used in this study was obtained from a local meteorological station.
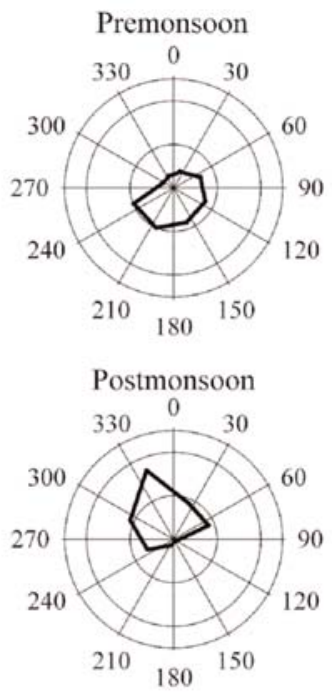
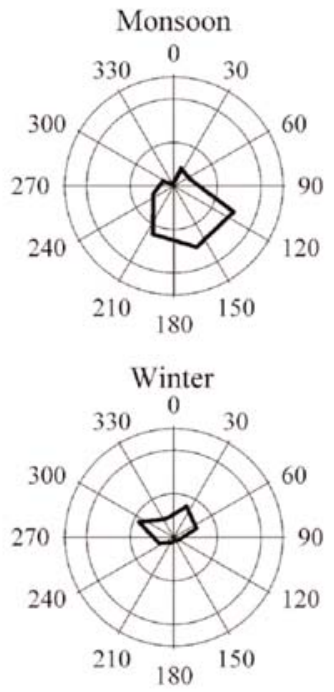

Fig. 3: Seasonal wind directions at Chittagong

\section{Results and Discussion}

Seasonal variation of the ground-level ozone and NOx concentrations

The variation of ozone concentrations during the study periods is shown in Figure 4. The lower and upper limit of the box represents the 25 th and 75 th percentile of the data. It has been observed that in June, ozone concentration becomes very low when NO concentration becomes high. It is known that ground level ozone is mainly generated from $\mathrm{NO}_{\mathrm{x}}$ and VOC, which mainly come from diesel or petrol vehicles, through photochemical reactions.
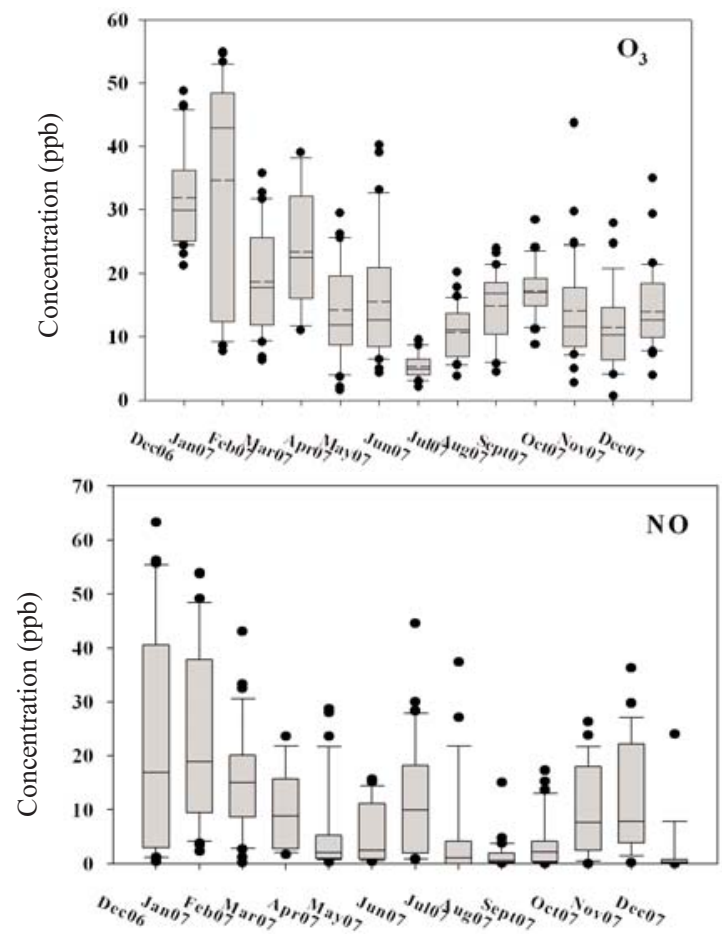

Fig. 4: Variation of $\mathrm{O}_{3}$ and $\mathrm{NO}$ concentrations in months of a year

The formation of ozone in the ground level results from the reaction between atomic oxygen $(\mathrm{O})$ and molecular oxygen $\left(\mathrm{O}_{2}\right)$.

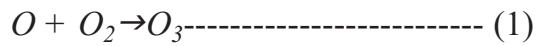

The oxygen atoms are produced primarily from photolysis of $\mathrm{NO}_{2}$ by the ultraviolet portion of solar radiation $(h v)$.

$\mathrm{NO}_{2}+h v \rightarrow \mathrm{NO}+\mathrm{O}_{2}$

Reaction (3) converts ozone back to oxygen and NO back to $\mathrm{NO}_{2}$, completing the "nitrogen cycle."

$\mathrm{O}_{3}+\mathrm{NO} \rightarrow \mathrm{NO}_{2}+\mathrm{O}_{2}$

Reactions 1 and 3 are comparatively fast. Therefore, the slower photolysis reaction (2) is usually the rate-limiting reaction for the nitrogen cycle and for this reason ozone is not formed appreciably at night. It is also of the reasons why ozone concentrations are high during the summer months, when temperatures are high and solar radiation is intense. The cycle time for the three reactions described above is 
only a few minutes. Ozone accumulates over several hours, depending on emission rates and meteorological conditions. Therefore, the nitrogen cycle operates fast enough to maintain a close approximation to the following photostationarystate equation derived from the above reactions. The $\mathrm{NO}_{\mathrm{x}}$ is the mixture of $\mathrm{NO}$ and $\mathrm{NO}_{2}$.

So, the $\mathrm{NO}_{\mathrm{x}}$ concentrations during the study period was also plotted and given in Figure 5. Hence when $\mathrm{NO}_{x}$ becomes high, the concentration of $\mathrm{HNO}_{3}$ will also be high. This $\mathrm{HNO}_{3}$ reacts with $\mathrm{NH}_{4}{ }^{+}$ion and easily form $\mathrm{NH}_{4} \mathrm{NO}_{3}$. Due to the policy intervention, and also low cost of $\mathrm{CNG}$, most of the light duty vehicles in Chittagong run by compressed natural gas $(\mathrm{CNG})$. As a result the concentration of $\mathrm{NO}_{x}$ in air has reduced from the previous year. In addition to this, as Chittagong is the largest port city, the diesel trucks, which run within the city, have also converted into $\mathrm{CNG}$. The increasing use of CNG in vehicles could be a cause of reducing ambient $\mathrm{NO}_{x}$ concentration in Chittagong. As a result the $\mathrm{O}_{3}$ concentration has also been reduced.

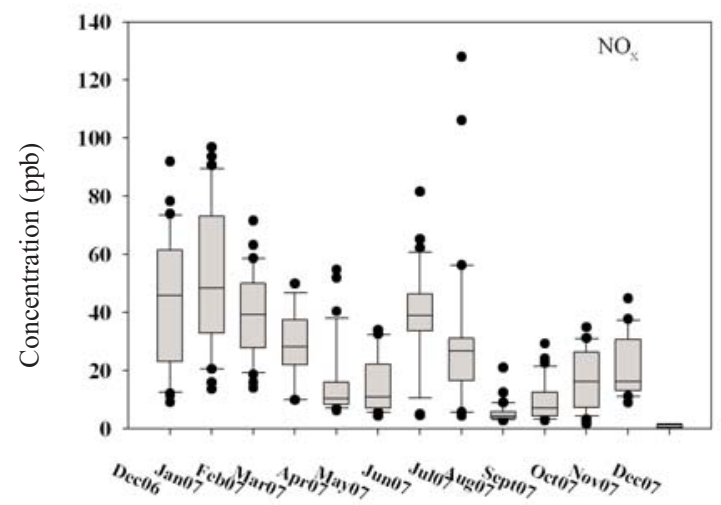

Fig. 5: Variation of $\mathrm{NO}_{\mathrm{x}}$ concentration during months study period

\section{Correlation of ozone between $\mathrm{NO}_{x}$ and $\mathrm{CO}$}

The scatter plot of $\mathrm{O}_{3}$ vs $\mathrm{CO}$ is given is Figure 6. This plot shows that $\mathrm{CO}$ and $\mathrm{O}_{3}$ do not come from the same source. This ground level ozone is the secondary pollutant, which comes from the reaction between NOx and VOC.

The scatters plot of $\mathrm{NO}_{\mathrm{x}}$ vs $\mathrm{O}_{3}$ concentration in given in Figure 7. This plot shows that they come from the same source. Here, $\mathrm{NO}_{\mathrm{x}}$ is the mixture of $\mathrm{NO}$ and $\mathrm{NO}_{2}$ concentrations.

As the number of vehicles during the daytime is higher than nighttime, therefore the concentration of NO is higher than $\mathrm{NO}_{2}$ (Figure 8). Meteorological conditions and anthropogenic exhaustion made a basic impact on seasonal distribution of the concentration of ground-level ozone.

\section{Diurnal variation in the ground-level ozone concentration}

In order to plot diurnal variation, the fifteen minutes average data for $\mathrm{NO}$ and $\mathrm{O}_{3}$ were taken. It has been found that when the $\mathrm{NO}$ concentration is minimal, the $\mathrm{O}_{3}$ formation becomes maximal (Figure 9). Winds disperse and dilute both $\mathrm{NO}_{\mathrm{x}}$ and ozone. For ozone, depending mixing layer may cause its concentration to decrease on some days and increase on others. During night, $\mathrm{NO}$ and ozone combine to form $\mathrm{NO}_{2}$ and oxygen until either the $\mathrm{NO}$ or ozone is consumed. Nitrous acid is produced from $\mathrm{NO}_{2}$ and water and is also emitted from various combustion sources. The level of HONO is low during daytime because sunlight breaks it down rapidly. At sunrise, sunlight causes gas-phase HONO to react rapidly to provide $\mathrm{NO}$ and $\mathrm{OH}$, to key reactants in the formation of ozone. In this way they help to initiate ozone formation in the morning by being available to react with VOCs as soon as their emissions increase due to an increase in human activity. The ground-level ozone formed in presence of the solar radiation. In this measurement periods, the concentration

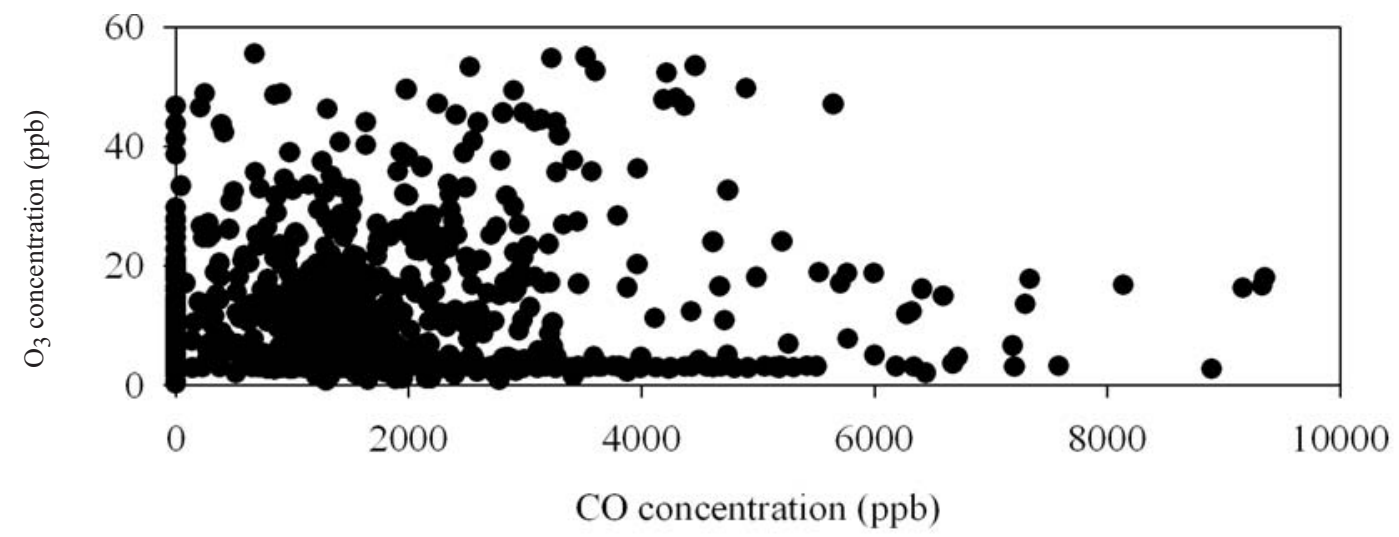

Fig. 6: The scatter plot between $\mathrm{CO}$ and $\mathrm{O}_{3}$ concentration 


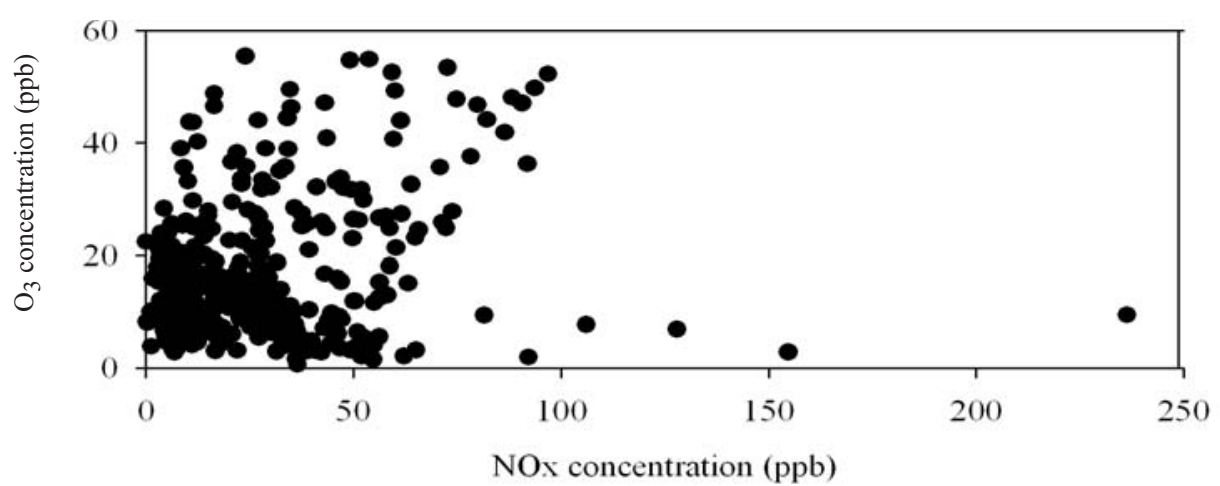

Fig. 7: The scatter plot between $\mathrm{NO}_{\mathrm{x}}$ and $\mathrm{O}_{3}$ concentration

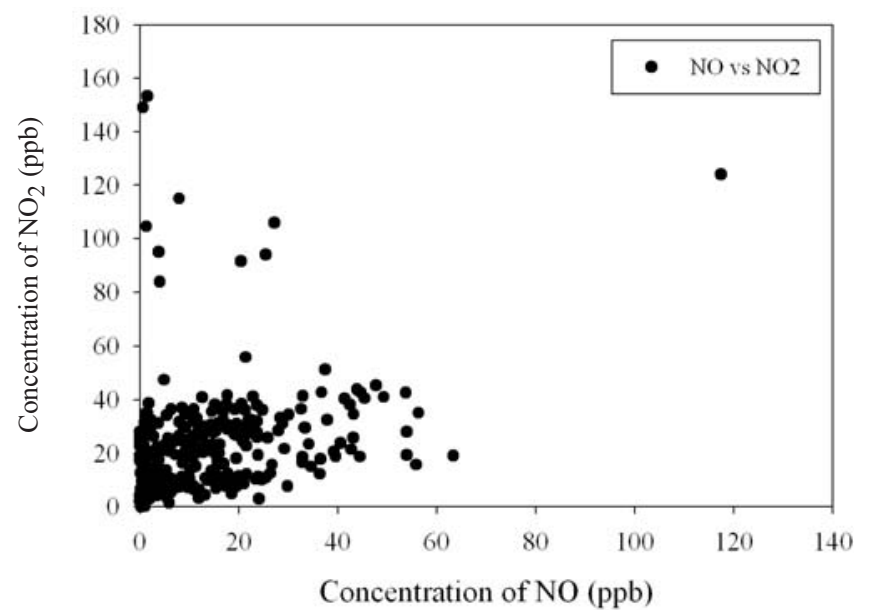

Fig. 8: The scatter plot between $\mathrm{NO}$ and $\mathrm{NO}_{2}$ concentration

of ground-level ozone had not exceed the BNAAQS value, which was set $80 \mathrm{ppb}$ (annual average).
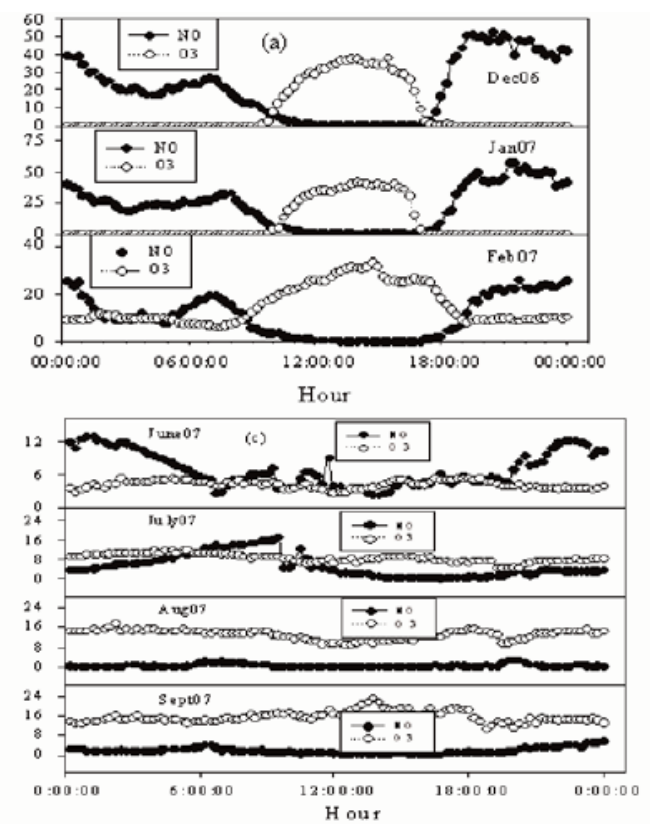

Relationship of Ground-level ozone concentration with meteorological parameters

To assess the relation with meteorological parameters the correlation coefficients between the ground-level ozone concentration and meteorological variables (air temperature and wind speed) have been calculated.

The results of this research have revealed that the groundlevel ozone concentration is markedly correlated with temperature $\left(r^{2}=0.42\right.$, Figure 10a) but poorly correlated with wind speed $\left(r^{2}=0.09\right.$, Figure $\left.10 \mathrm{~b}\right)$. The air temperature determines vertical movements of air pollutants. Under normal condition, the warm air near the soil surface causes pollutants to rise vertically. Pollutants rapidly become dilute and blown away by upper level winds. At low wind speed, the concentration is very high whereas at higher wind speed, the concentration becomes low due to dispersion.
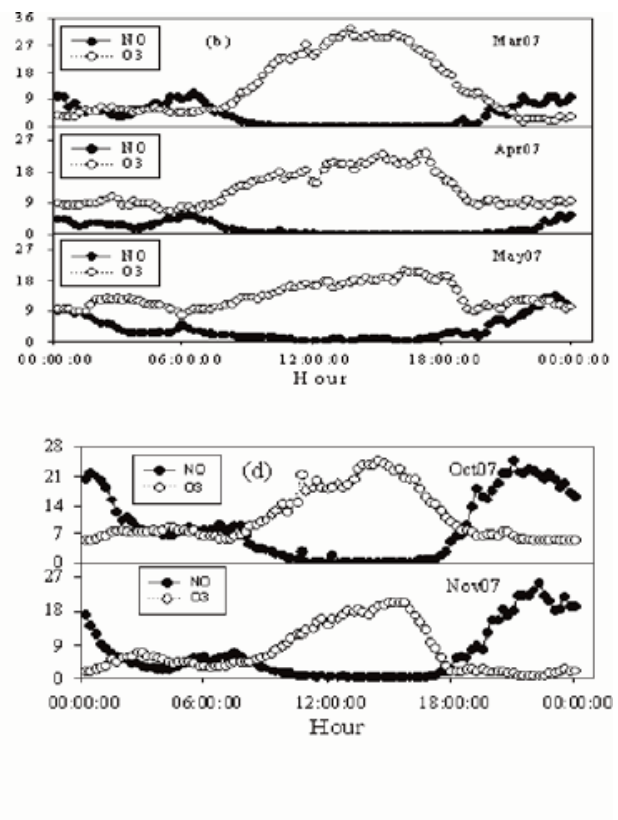

Fig. 9: Diurnal variation in the ground-level ozone formation during winter (a), pre- monsoon (b), monsoon (c) and post-monsoon (d) respectively 

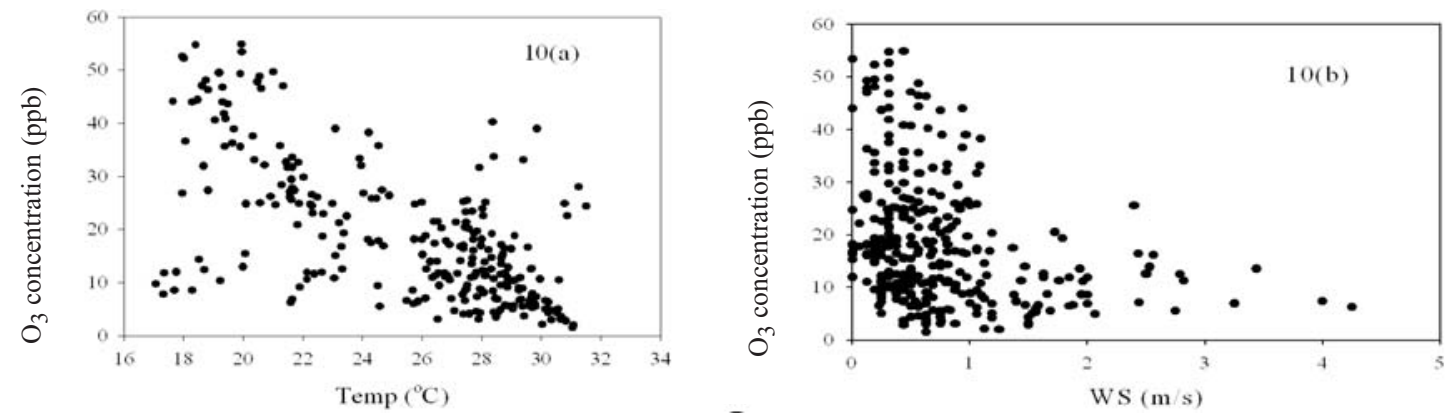

Fig. 10: Correlation between the ground-level ozone concentration and meteorological variables a) correlation between ozone concentration and temperature and b) correlation between ozone concentration and wind speed

\section{Conclusion}

Ground-level ozone is known as a product of complex photochemical processes involving nitrogen oxides $\left(\mathrm{NO}_{x}\right)$ and volatile organic compounds (VOCs) as main precursors. Main sources of nitrogen oxides and volatile organic compounds in urban areas are transport and industrial activities. Results of this study show overall ground-level ozone concentration in Chittagong city, which is lower than the BNAAQS. The ground level ozone concentration is characterized by the specific seasonal variation. The highest concentration is found in winter season. The ground-level ozone concentration has also clear diurnal cycle, with higher values in the daytime and notably zero values at night (Millan et al, 2000). Lee et al. also reported that ozone concentration gradually increased after sunrise and decreased in the evening.

The ground-level ozone concentration depends on meteorological conditions (temperature, wind speed and direction). From this study a significant positive correlation was found between the ground-level ozone concentration and temperature $\left(r^{2}=0.42\right)$. The other authors also reported the same correlation (Olszyna et al, 1997 and Laurinaviciene, 2009). Like the other authors (Laurinaviciene, 2009 and Liuria et al 2008) we also get the inverse correlation between wind speed and ozone.

\section{Acknowledgement}

We would like to thank the Project Director, AQMP, DOE, Deputy Director (Laboratory), Deputy Director (Accounts), AQMP, and the AQMP Technical Staff for providing the background information and gaseous pollutants data in Chittagong required for this study. The Authors thankfully acknowledge their cooperation.

\section{References}

Cristofanelli P. and Bonasoni P. (2009). Background ozone in the southern Europe and Mediterranean area: Influence of the transport and processes. Environ. Pollu., 157: 1399.

Pudasainee D., Sapkota B., Manohar L. S., Kaga A., Kondo A. and Inoue Y. (2006). Ground level ozone concentrations and its association with NOx and meteorologi- cal parameters in Katmandu valley, Nepal. Atmos. Environ., 40: 8081.

Parra M. A., Elustando D., Bermejo R., Santamaria. J. M. (2009). Ambient air levels of volatile organic compounds (VOC) and nitrogeh dioxide $\left(\mathrm{NO}_{2}\right)$ in a medium size city in Northern Spain. Sci.of the Total Environ., 407: 999.

Jacob D. J., and Winner. D. A. (2009). Effect of climate change on air quality. Atmos. Environ., 43: 51.

Hunova I., Santroch J. and Ostatnicka. J. (2004). Ambient air quality and deposition trends at rural stations in the Czech Republic during 1993-2001. Atmos. Environ., 38: 887 .

Begum B. A., Biswas S. K. and Hopke. P. K. (2006). Temporal variations and spatial distribution of ambient PM2.2 and PM10 concentrations in Dhaka, Bangladesh. Sci. of the Total Environ. 358: 36.

Millan M. M., Mantilla E., Salvador R., Carratala A., Sanz M. J., Alonso I., Gangoiti G. and Navazo. M. (2000). Ozone cycles in the Western Mediterranean Basin: interpretation of morning data in complex coastal terrain. J Appl. Meteorol., 39: 487.

Lee S. H., Sung K. H. and Lee. H. W. (2008). Impact of regional trans-boundary ozone associated with complex terrain on urban air quality. Atmos. Environ., 42: 7384.

Olszyna K. J., Luria M. and Meagher J. F. (1997). The correlation of temperature and rural ozone levels in southeastern USA. Atmos. Environ., 31: 3011.

Laurinaviciene. D. (2009). Ground-level Ozone air pollution in Vilnius city. Environmental Research, Engin. and Manage.,49: 21.

Luria M., Valente R. J., Bairai S., Parkhurst L. and Tanner R. L. (2008). Airborne study of ozone formation over Dallas, Texas. Atmos. Environ., 42: 6951.

Received : May 11, 2011;

Accepted : August 23, 2011 